\title{
Methane production in aerobic oligotrophic surface water in the central Arctic Ocean
}

\author{
E. Damm ${ }^{1}$, E. Helmke ${ }^{1}$, S. Thoms ${ }^{1}$, U. Schauer ${ }^{1}$, E. Nöthig ${ }^{1}$, K. Bakker ${ }^{2}$, and R. P. Kiene ${ }^{3,4}$ \\ ${ }^{1}$ Alfred Wegener Institute for Polar and Marine Research, P.O. Box 12061, 27515 Bremerhaven, Germany \\ ${ }^{2}$ Royal Netherlands Institute for Sea Research, Texel, The Netherlands \\ ${ }^{3}$ Department of Marine Sciences, University of South Alabama, Mobile, Alabama, USA \\ ${ }^{4}$ Dauphin Island Sea Lab, Dauphin Island, Alabama, USA
}

Received: 30 September 2009 - Published in Biogeosciences Discuss.: 11 November 2009

Revised: 25 February 2010 - Accepted: 5 March 2010 - Published: 19 March 2010

\begin{abstract}
A methane surplus relative to the atmospheric equilibrium is a frequently observed feature of ocean surface water. Despite the common fact that biological processes are responsible for its origin, the formation of methane in aerobic surface water is still poorly understood. We report on methane production in the central Arctic Ocean, which was exclusively detected in Pacific derived water but not nearby in Atlantic derived water. The two water masses are distinguished by their different nitrate to phosphate ratios. We show that methane production occurs if nitrate is depleted but phosphate is available as a $\mathrm{P}$ source. Apparently the low N:P ratio enhances the ability of bacteria to compete for phosphate while the phytoplankton metabolite dimethylsulfoniopropionate (DMSP) is utilized as a C source. This was verified by experimentally induced methane production in DMSP spiked Arctic sea water. Accordingly we propose that methylated compounds may serve as precursors for methane and thermodynamic calculations show that methylotrophic methanogenesis can provide energy in aerobic environments.
\end{abstract}

\section{Introduction}

Methane supersaturation within the oxygenated ocean surface mixed layer is widespread and has been known for more than three decades (Lamontagne et al., 1973, Scranton and Brewer, 1977; Forster et al., 2008). Although biological processes are considered to be responsible, the so called methane paradox i.e. methanogenesis in an aerobic environment is not yet explained. In particular, the mechanism of

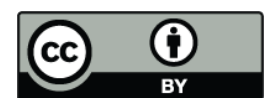

Correspondence to: E. Damm (ellen.damm@awi.de) methane formation needs to be understood in order to estimate its global significance.

The role of nutrient limitation, particularly phosphate stress, has only recently been discussed as a possible regulator of methane production (Karl et al., 2008). These authors suggested that under P limitation, microorganisms utilized more organic phosphorus compounds, and they demonstrated experimentally that exogenous methylphosphonate can be converted to methane.

We report here that in the central Arctic Ocean methane formation apparently occurs in phosphate-replete Pacificderived water (Pdw) whereas no net methane accumulation is observed in phosphate-poor Atlantic-derived water (Adw) nearby.

The two water masses differ in their nitrate/phosphate relationship (Jones et al., 1998) due to an excess of phosphate over nitrate in Pdw (Yamamoto-Kawai et al., 2006). We discuss the different stages of oligotrophy established in the two water masses as an obvious requirement for triggering the switch from a situation of no methane production to one of methane production.

Complementary to the role of nutrient limitations, we discuss the potential role of DMSP (dimethylsulfoniopropionate) degradation products as precursors for methane formation and propose methylotrophic methanogenesis as the principal pathway.

DMSP is an abundant methylated substrate in the surface ocean and large amounts are produced annually by phytoplankton (Stefels, 2000). Recently an inverse correlation between DMSP and methane in polar water was observed (Damm et al., 2008). DMSP can be degraded by a cleavage and a demethylation pathway (Kiene et al., 2000). The best known cleavage product of DMSP is DMS (dimethylsulfide).

Published by Copernicus Publications on behalf of the European Geosciences Union. 
DMS escapes partly to the atmosphere where it is the most important natural climate-cooling gas, counterbalancing the effect of greenhouse gases (Charlson et al., 1987). Most of the dissolved DMSP, however, is sequentially demethylated. Aerobic as well as anaerobic demethylation pathways are known to provide bacteria with energy and carbon sources for biosynthesis (Kiene et al., 2000). An intermediate product of both pathways is methanethiol. Its anaerobic metabolism to methane was described by Tallant and Kryzcki (1997). In addition, a new metabolic pathway for anaerobic methane oxidation was recently proposed, where methane serves as electron donor and methanethiol is created as intermediate product (Moran et al., 2008).

We discuss this type of metabolism in its reverse direction and calculate the energy yield associated with this pathway.

\section{Regional setting}

The Arctic Ocean circulation comprises both low salinity and nutrient-rich Pacific Ocean water and relatively nutrient-poor and more saline Atlantic Ocean water (Pabi et al., 2008). The Atlantic water enters through the Fram Strait and the Barents Sea and is distributed via counterclockwise currents in the Eurasian sector. Pacific water enters the Arctic basin through the Bering Strait via the Chukchi Sea and exits through the Canadian Archipelago and the western Fram Strait. Because the broad shelves of the Bering and Chukchi Seas are denitrification sites, water of Pacific origin is continuously depleted in nitrate relative to phosphate during its journey from the entrance at the Bering Strait via the central Arctic to its outflows (Yamamoto-Kawai et al., 2006). In the early nineties, the front separating the Atlantic and the Pacific water has been located over the Alpha-Mendeleev Ridge (Carmack et al., 1997, Pabi et al., 2008). Hence, in the central Arctic Ocean (north of $85^{\circ} \mathrm{N}$ ) the influence of Pacific water is restricted to the region west of the $180^{\circ}$ longitude.

On the Arctic shelves huge amounts of submarine methane are stored in hydrates, source rocks and permafrost sediments and when released causes excess methane in shelf water, as was observed in the Beaufort Sea (Mac Donald, 1976; Kvenvolden et al., 1993), in the Laptev and East Siberian Sea (Shakhova and Semiletov, 2007) as well as in the Barents Sea (Lammers et al., 1994; Damm et al., 2005). Plume spreading in the stratified shelf water transports dissolved methane mainly along isopycnals into the deeper and dense shelf water but methane also escapes into surface water by vertical mixing (Jeong et al., 2004; Damm et al., 2005). However, offshore transports of dissolved methane are rapidly reduced by open ocean dispersion, sea to air flux and methane oxidation processes. Thus, the central Arctic, which is nearly $1000 \mathrm{~km}$ away from the shelves, is not influenced by excess methane from the shelves (T. D. Lorenson, personal communication, 2009). Shelf sources of the elevated methane values in Pdw are unlikely because of the long transfer times of the water between the nearest shelf sea (Chukchi Sea) and the study area. Although no direct near-surface velocity measurements are available indirect estimates suggest travel times of several months from the shelf edge to our section. Sea ice takes more than two years to cross the Arctic in the fastest passage, the Transpolar Drift, and it is expected to drive rather than to slow down the surface waters. Woodgate et al. (2005) estimate that Pdw takes several months to transit the Chukchi Sea and we assume that this speed holds also for the passage of the deep ocean.

\section{Data and methods}

Two transects were sampled in the central Arctic during an expedition with the research vessel "Polarstern" in September 2007 (Schauer et al., 2008). Both transects cross from $130^{\circ} \mathrm{E}$ to $130^{\circ} \mathrm{W}$ roughly along the $85^{\circ} \mathrm{N}$ latitude (Fig. 1). The Atlantic-derived water was detected between approximately $130^{\circ} \mathrm{E}$ and $180^{\circ}$. On the stations further west, i.e. from $180^{\circ}$ to $130^{\circ} \mathrm{W}$, the proportion of Pacific-derived water increases. In the following, methane concentration and ancillary data will be categorized as part of either Atlanticderived water (Adw) or Pacific-derived water (Pdw) (Fig. 1).

Salinity and temperature were measured with a Seabird SBE 911 plus CTD. Water samples from up to eight different depths were collected during the upcast at each CTD station with $10 \mathrm{~L}$ Niskin bottles mounted on a rosette sampler.

Estimates of phytoplankton biomass and abundances of dominant unicellular organisms were obtained from samples out of the $10 \mathrm{~m}$ water depth Niskin bottle. For the chlorophyll $a$ determination, $0.5-2.0 \mathrm{~L}$ of water were filtered through Whatman GF/F glass-fiber filters and stored at $-18^{\circ} \mathrm{C}$ and later analyzed in the home laboratory. The filters were extracted in $90 \%$ acetone and analyzed with a spectrophotometer for higher values and with a Turner-Design fluorometer for lower values according to the methods described in Edler (1979) and Evans and O'Reily (1984). The values from the fluorometer were calibrated with a spectrophotometer, using authentic chlorophyll $a$ (Sigma). Phyto- and protozooplankton samples were preserved in hexamine-buffered formalin in brown glass bottles. A minimum of 50-100 cells of the dominant species or groups were counted in aliquots of $50 \mathrm{ml}$ settled for $48 \mathrm{~h}$, under an inverted microscope. Here we only present cell counts for species or groups which were easy to recognize in the samples. For the diatoms only vegetative cells were used for the calculations since resting cells have a fairly low metabolism.

Sampling for nutrient analyses was carried out directly from the Niskin bottles. The samples were kept cool and dark and analyzed within $10 \mathrm{~h}$ using a Technicon TRAACS 800, continuous flow auto-analyzer. Phosphate was measured according to Murphy and Riley (1962) and nitrate according to Grasshoff et al. (1983). 
Methane concentration was analyzed within hours of sampling. The dissolved gas was extracted from water by vacuum-ultrasonic treatment and subsequently measured with a gas chromatograph (Chrompack 9003, GC) with flame ionization detector (FID). For gas chromatographic separation we used a packed column (Porapac Q 80/100 mesh). The $\mathrm{GC}$ oven was operated isothermally $\left(60^{\circ} \mathrm{C}\right)$ and the heated zone of the FID was held at a temperature of $250^{\circ} \mathrm{C}$. Two sets of standard gas mixtures (10 and $100 \mathrm{ppmv}$ ) were used for calibration. The standard deviation of duplicate analyses was 5\%. This high overall error is almost exclusively due to the gas extraction procedure and not to GC precision, which had an error of only $1 \%$. After GC analyses, the remainder of the gas was transferred into evacuated glass containers for analysis of the carbon isotopic signature on shore.

The $\delta^{13} \mathrm{C}_{-} \mathrm{CH}_{4}$ values were determined by a Delta XP plus, Finnigan mass spectrometer. The extracted gas was purged and trapped with PreCon equipment (Finnigan) to pre-concentrate the sample. Depending on the concentration of methane, the reproducibility derived from duplicates was 0.5-1\%o. Isotopic ratios are reported relative to the Pee Dee Belemnite (PDB) standard using conventional delta notation (Craig, 1957).

DMSPt (DMSPtotal) samples were collected directly from Niskin sample bottles into $50 \mathrm{ml}$ centrifuge tubes that contained $167 \mu \mathrm{l}$ of $50 \% \mathrm{H}_{2} \mathrm{SO}_{4}$. The tubes were sealed and the samples stored for later analysis on shore. DMSPt is stable for months in acid solution (Curran et al., 1998). DMSPt in the stored samples was analyzed as DMS after alkaline cleavage. A subsample of the solution was pipetted into a $14 \mathrm{ml}$ serum vial and treated with $1 \mathrm{ml}$ of $5 \mathrm{~N} \mathrm{NaOH}$ and quickly sealed. The released DMS was purged into a cryotrap and quantified with a gas chromatograph equipped with a Chromosil 330 column and a flame photometric detector. The oven temperature was $100^{\circ} \mathrm{C}$ and Helium was used as the purge and carrier gas. The analytical system was calibrated for DMS with standards. The detection limit was 0.5 to 1 pmol DMS injected, which yielded DMSP detection limits of 0.17 to $0.33 \mathrm{nM}$ in a $3-\mathrm{mL}$ sample.

A microcosm experiment was set up to study the ability of natural Arctic bacterial communities to produce methane from DMSP. Sea water sampling, incubation and methane measurements were conducted in the Greenland Sea in 2008 $\left(77^{\circ} 59.9^{\prime} \mathrm{N} 12^{\circ} 0.19^{\prime} \mathrm{W}\right)$. Seawater was transferred from $10 \mathrm{~L}$ Niskin bottles into sterile 1 liter glass bottles with silicone membranes. Immediately after water sampling five bottles were spiked with $50 \mu \mathrm{M}$ DMSP. Five bottles served as controls which were free of DMSP supplements. The methane concentration was measured as described above. Measurements were conducted at the beginning of the experiment and after 3, 6, 8, 10 and 12 days by sacrificing one bottle spiked with DMSP and one control bottle at each time point. The incubation was carried out at approximately in situ temperature (about $1^{\circ} \mathrm{C}$ ) in artificial daylight to simulate the polar summer situation. The composition of the bacterial communities developed in the bottles spiked with DMSP was determined after 6,8 , and 10 days by means of CARD-FISH as well as DGGE-analysis. The DGGE analysis was conducted at the start of the experiment and after 8 and 10 days using $600 \mathrm{ml}$ of each sample.

Total bacterial counts were determined by epifluorescence microscopy of acridine orange-stained cells after Hobbie et al. (1977).

Denaturing gradient gel electrophoresis (DGGE) analysis based on the 16S rRNA gene was used to examine the diversity of natural bacterioplankton assemblages as well as the bacterial consortia grown in the microcosm experiments. Plankton cells concentrated by centrifugation were freezedried and stored deep frozen until DNA analyses. Bacterial cells of the microcosm experiments were sampled on $\mathrm{Nu}$ clepore filters $(0.2 \mu \mathrm{m}$ pore size). Total community DNA was extracted using the Ultraclean soil DNA kit (MoBio Laboratories, USA). To increase the sensitivity of PCRamplification and DGGE-analysis, a non-specific amplification step was applied with the natural bacterial community using the GenomiPhi DNA Amplification Kit (GE Healthcare) as specified by the manufacturer. One $\mu \mathrm{l}$ product of the GenomiPhi reaction and 1 to $5 \mu$ original DNA extract of the microcosm experiments were applied as template in the 16S rRNA gene specific PCR with GM5 plus GC-clamp as forward primer and 907RM as reverse primer. PCR conditions were as, described by Gerdes et al. (2005). PCRproducts were analyzed by DGGE, based on the protocol of Muyzer et al. (1993) using a gradient-chamber. Significant bands from the DGGE-pattern were selected and, after excision from the gel, re-amplified by PCR as described by Gerdes et al. (2005). The 16S rRNA gene amplicons were sequenced and the sequences compared to those deposited in GenBank using the BLAST algorithm.

Amplification of nifH gene fragments was performed to screen for dinitrogen fixing bacteria. The DNA-products of the GenomiPhi amplification reaction and the extracts of the microcosm-experiment respectively were employed in the nifH gene specific PCR-reaction using the forward primer nifH-f (5'-TAYGGNAARGGNGGNATYGGNAARTC-3'), designed by Boulygina et al. (2002), and the reverse primer nifH-r (5'-ADNGCCATCATYTCNCC-3'), designed by Zehr and McReynolds (1989). Details of the amplification conditions are given by Dedysh et al. (2004).

Catalyzed reporter deposition (CARD) - Fluorescence in situ hybridization (FISH) was employed to characterize the structure of the bacterial communities, which developed in the microcosm-experiments. Water samples were fixed with buffered paraformaldehyde solution. After about $2 \mathrm{~h}$ the cells were immobilized on white polycarbonate filters and rinsed with phosphate-buffered saline and distilled water. Air-dried filters were stored at $-20^{\circ} \mathrm{C}$ until further processing. CARD-FISH analysis was conducted according to the method of Pernthaler et al. (2002) using horseradish peroxidase (HRP)-labeled oligonucleotide probes (ThermoHybaid; 

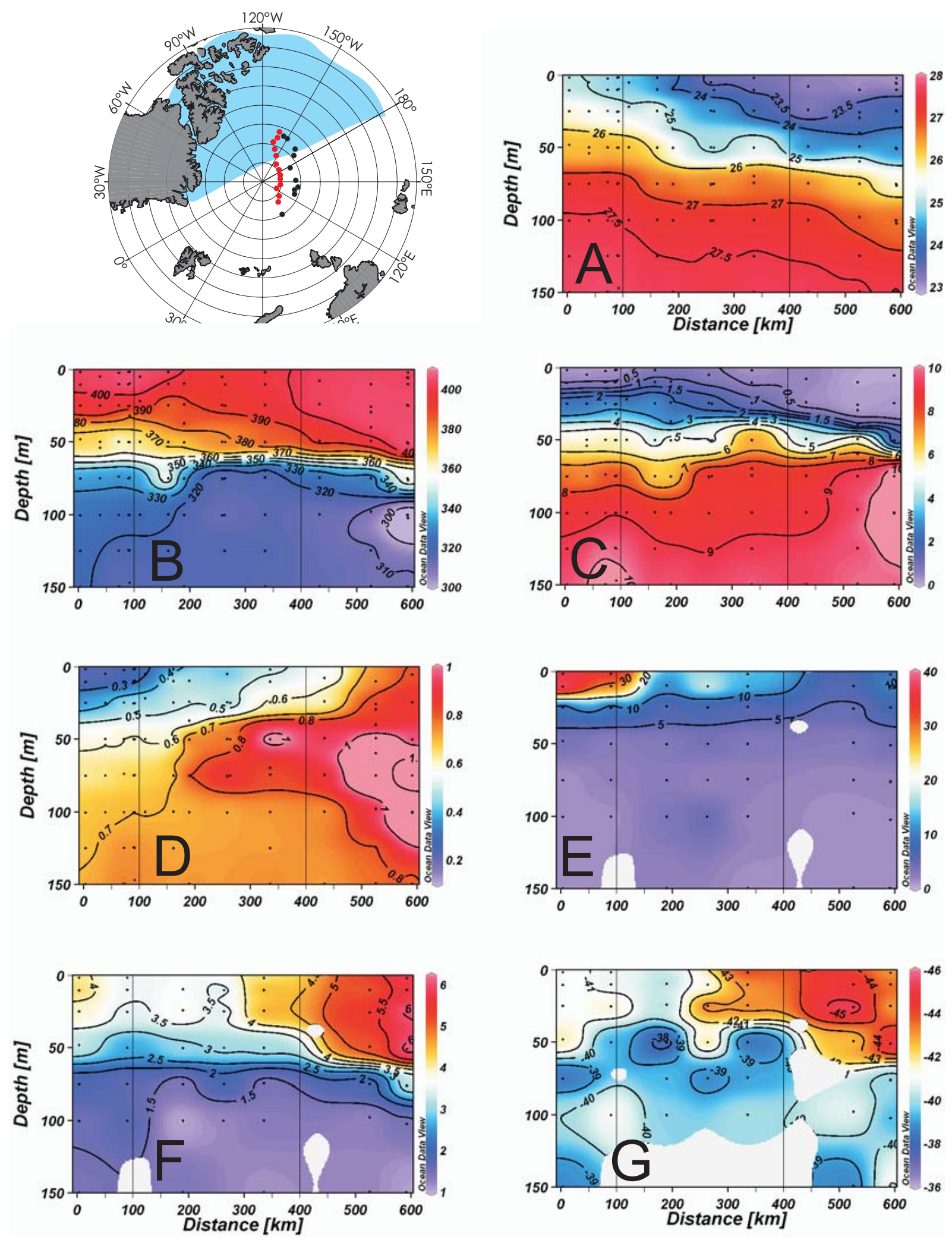

Fig. 1. Map of the central Arctic Ocean showing the spread of Pacific/Atlantic water as blue and colorless areas, respectively. Dots indicate stations along two transects. Profiles for red transect running from east to west are shown in diagrams (A) to (G). (A) shows the potential density in sigma $\theta$ units, $(\mathbf{B})$, the concentration of oxygen $\left.(\mu \mathrm{mol} / \mathrm{L}),(\mathbf{C}), \mathrm{NO}_{3}(\mu \mathrm{mol} / \mathrm{L}),(\mathbf{D}), \mathrm{PO}_{4}(\mu \mathrm{mol} / \mathrm{L})(\mathbf{E}), \mathrm{DMSPt}_{(} \mathrm{nM}\right),(\mathbf{F}), \mathrm{CH}_{4}$ $(\mathrm{nM})$ and (G), $\delta^{13} \mathrm{C}-\mathrm{CH}_{4}$ as (\%o PDB). 
Ulm, Germany) with Alexa546 as the reporter signal. The standard set of oligonucleotide probes were applied specific for the kingdoms of Eubacteria and Archaea, for the domain Bacteroidetes and the subclasses alpha- and gammaproteobacteria. The probe Non338 (Wallner et al., 1993) was used to test for non-specific probe binding. Hybridization temperature was $35^{\circ} \mathrm{C}$. Air-dried hybridized samples were counterstained with 4', 6'-diamidino-2-phenylindole (DAPI; final concentration $1 \mu \mathrm{g} \mathrm{ml}^{-1}$ ). Samples were evaluated under an Axioplan2 epifluorescent microscope equipped with appropriate filter sets for Alexa546 and DAPI fluorescence. Between 800 and 2000 DAPI-stained objects were counted per probe and sample.

\section{Results and discussion}

\subsection{Excess methane in Pacific derived surface water}

Fresh water anomalies traced in the past decade between the East Siberian Sea (Jones et al., 2008) and Fram Strait (Rabe et al., 2009) suggest that several years are needed for surface waters to cross the deep Arctic Basin. Additional sea-ice cover in the central Arctic impedes the gas exchange between atmosphere and ocean. Hence, under-ice methane consumption is the main process which determines the methane inventory in the central Arctic Ocean. As a result concentration becomes more and more depleted relative to the atmospheric equilibrium concentration while at the same time the residual methane becomes increasingly enriched in ${ }^{13} \mathrm{C}$ in relation to the atmospheric carbon isotopic signature of methane (Damm et al., 2007).

The isolation from the atmosphere and ongoing consumption are clearly reflected in subsurface water (water depth $>100 \mathrm{~m}$ ) where the effects of under-ice consumption remain conserved due to the density of the highly stratified water column, which restricts vertical mixing during summer (Fig. 1). In comparison, near-surface water (water depth $<100 \mathrm{~m}$ ) is influenced by air-sea gas exchange during summer and as a result, methane tends to equilibrate with the atmospheric background. In polar water, methane concentration in equilibrium with atmosphere is estimated to range between 3.5 and $4 \mathrm{nM}$. Actually, in Adw, the concentration is close to atmospheric equilibrium and reflects an air-sea methane exchange, which is also confirmed by the $\delta^{13} \mathrm{C}_{-}-\mathrm{CH}_{4}$ values (from -41 to $-43 \%$ PDB). These correspond to a two component mixing between reservoirs with different isotopic compositions i.e. the $\delta^{13} \mathrm{C}_{-} \mathrm{CH}_{4}$ value of the local marine background ( $-38 \%$ PDB in subsurface water) and the $\delta^{13} \mathrm{C}_{-} \mathrm{CH}_{4}$ value of the atmospheric reservoir $(-47 \%$ o PDB) (Fig. 1). However, in Pdw, the methane concentration is clearly elevated relative to the equilibrium level. Furthermore, the methane is more enriched in ${ }^{12} \mathrm{C}$ compared to that in Adw (up to $-46 \%$ PDB). These two features combined, are indicative of methane production in Pdw (Fig. 1).

\subsection{Phytoplankton bloom and nutrient availability}

Primary production in the central Arctic is essentially regulated by sea ice dynamics. The melting ice exposes the nutrient-rich surface waters to more light, which triggers the phytoplankton bloom. However, nutrients in near-surface water are rapidly exhausted as the density stratification inhibits an upward transport and replenishment of nutrients (Sakshaug, 2003). High phosphate and nitrate concentrations are therefore present in subsurface water $(>50 \mathrm{~m}$ water depth).

In near-surface water nitrate becomes depleted and eventually exhausted in the top layers. Phosphate, however, is only limited in Adw, while in Pdw excess phosphate remains available up to the sea surface (Fig. 1). Nitrate and phosphate are the primary regulators of phytoplankton growth and consequently varying availability induces different bloom stages in the two water masses.

Low chlorophyll $a$ concentrations were generally encountered, with those in the $\mathrm{Pdw} 0.11 \mu \mathrm{g} / \mathrm{L}$ (range 0.06$0.22 \mu \mathrm{g} / \mathrm{L}$ ) being lower than in Adw $0.33 \mu \mathrm{g} / \mathrm{L}$ (range 0.19 $0.48 \mu \mathrm{g} / \mathrm{L}$ ). The composition and the size of unicellular plankton organisms also varied in the two water masses. In Adw, diatoms (55\%) were the dominant species followed by nanoflagellates $(31 \%)$, ciliates and dinoflagellates $(12 \%)$ while in Pdw small nanoflagellates (85\%) clearly dominated. The plankton composition in Adw represented a late spring to summer phase of new production, while the nitrate and phosphate depletion in near-surface water reflected an exhausting bloom (Fig. 1).

In comparison, the composition and size of unicellular plankton organisms in Pdw reflect an impoverished phytoplankton community. As phosphate excess is available the phytoplankton growth is clearly limited by nitrate depletion (Fig. 1).

\subsection{Nutrient limitations and bacterioplankton composition}

During the phytoplankton growth the global mean ratio of 16:1 between nitrogen and phosphorous remains preserved if both are consumed and released in the same constant ratio, while shifts of this ratio are induced by increasing oligotrophy (Redfield, 1958). A perturbation of the Redfield ratio is expressed in the definition of $\mathrm{N}^{*}\left(\mathrm{~N}^{*}=(\mathrm{N}-\right.$ $16 \mathrm{P}+2.9 \mu \mathrm{mol} / \mathrm{kg}$ ) $\cdot 0.87$ ), a quasi-conservative tracer (Gruber and Sarmiento, 1997). N* is about zero if the Redfield ratio is retained, while positive and negative values of $\mathrm{N}^{*}$ are associated with deviations from the conservative behavior. Although deviations from the global mean Redfield ratio are evident in both water masses, $\mathrm{N}^{*}$ remains constant about $1.8 \mu \mathrm{mol} / \mathrm{kg}$ in Adw, in contrast to Pdw where $\mathrm{N}^{*}$ decreases from 1 to $-1.5 \mu \mathrm{mol} / \mathrm{kg}$ reflecting increasing perturbation (Fig. 2). Methane excess increases where nitrate is the only growth-limiting nutrient and $\mathrm{N}^{*}$ is decreasing. 


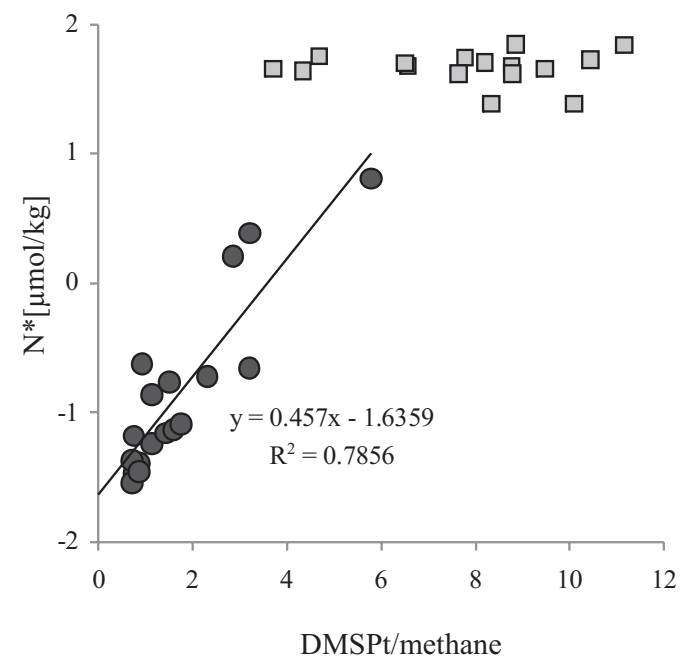

Fig. 2. Relationship between $\mathrm{N}^{*}$ and the DMSPt to methane ratio for water samples of the central Arctic Ocean. Circles and squares correspond to Pacific and Atlantic derived surface water $(<50 \mathrm{~m})$, respectively. $\mathrm{N}^{*}$ is a quasi conservative tracer concerning the $\mathrm{N}: \mathrm{P}$ ratio. $\mathrm{N}^{*}$ of about zero reflects a constant ratio while deviations from zero are induced by perturbations of the Redfield ratio (Gruber and Sarmiento 1997, see text). In Pacific derived water, the $\mathrm{DMSP}$ /methane ratio correlates with increasing deviations from the conservative $\mathrm{N}: \mathrm{P}$ ratio.

During phytoplankton senescence, the activity of bacterioplankton is stimulated by the release of nutrients and dissolved organic matter. In the central Arctic where only low bacterial biomass is detected (in Pdw on average $4.8 \times 10^{4}$ and in Adw on average $17.7 \times 10^{4}$ bacterial counts per ml) the quantity differences correspond to those of the chlorophyll between the two water masses.

The composition of the bacterioplankton in selected samples of the Adw and Pdw was examined by means of DGGE based on the phylogenetically relevant $16 \mathrm{~S}$ rRNA gene. In all water samples DGGE-bands of eukaryotic chloroplast DNA were found while only few bands could be assigned to prokaryotic taxa. A preponderance of sequences in the Pdw samples belonged to the alpha-proteobacteria subclass and these had very high similarities (99\%) to sequences of uncultured Sulfitobacter, Roseobacter, and Phaeobacter types within the family Rhodobacteraceae. Bacteria of the Rhodobacter/Roseobacter group are frequent in oligotrophic ocean surface waters but mostly uncultured. Cultured representatives of this group are known for their highly diverse and flexible metabolism. A survey of available Roseobacter genomes by Moran et al. (2007) revealed that $50 \%$ of the genomes contained genes for DMSP demethylation, $92 \%$ for phosphonate use, $25 \%$ for aerobic anoxygenic phototrophy, and $92 \%$ for carbon monoxide oxidation. Further, different strains of Rhodobacter sphaeroides are able to fix dinitrogen and possess the nifH (nitrogenase) gene (Moran et al., 2007). We could also amplify the nifH gene in the Pdw sam- ples suggesting that nitrogen depletion may in this case be compensated by dinitrogen fixation. Nitrogenases are generally oxygen sensitive and therefore often accommodated in separate cell compartments (Gallon, 1992). In such an environment in which hydrogen is produced by nitrogenases, we suggest that methane may be formed from methylated compounds by eubacteria e.g. alpha-proteobacteria.

\subsection{DMSP as precursors for methane formation in nitrate-stressed environment}

In oligotrophic water growth rates for the bacterioplankton are limited, either by mineral nutrients or by organic carbon (Thingstad et al., 2008). An important component for the bacterial carbon demand is DMSP (dimethylsulfoniopropionate) (Simo et al, 2002) and in microcosm experiments, a significant increase in bacterial biomass production is induced by the addition of DMSP as a C source while phosphate was the second limiting nutrient once $\mathrm{C}$ limitation was alleviated (Pinhassi et al., 2005). Consequently, phosphate availability may influence the utilization of DMSP as $\mathrm{C}$ source for bacterial biomass production.

In Pdw, excess phosphate is available for bacterial biomass production. The inverse correlation found between phosphate and DMSPt $\left(r^{2}=0.7\right)$, may be indicative of the following: First, the correlation simply indicates the increasing degree of oligotrophy. Second, the decreasing DMSPt concentration reflects an increasing utilization of DMSPt as carbon source in the Pdw where phosphate is available for the bacteria (Fig. 3). The following features corroborate this assumption. In Pdw, phosphate is also significantly correlated with methane $\left(r^{2}=0.9\right)$, (Fig. 3) and a correlation between DMSPt decrease and methane production has previously been found (Damm et al., 2008).

The differences in methane, DMSPt and nutrient cycling between Pdw and Adw are illustrated in the correlation/noncorrelation between $\mathrm{N}^{*}$ vs. the DMSPt/methane ratio respectively. We find a coupling of DMSPt decrease with methane formation on the one hand, while on the other the decreasing DMSPt/methane ratio is correlated with an increasing perturbation of the N:P ratio (i.e., more negative $\mathrm{N}^{*}$, Fig. 2). Thus, the coupling of several environmental factors is apparently obligatory for methane to be formed as a by-product of a yet unexplained metabolic pathway.

\subsection{Implications for a potential pathway}

\subsubsection{Methane formation in DMSP spiked sea water}

In a microcosm experiment using Arctic surface water we could show a microbial degradation of DMSP to methane (Fig. 4). After 12 days considerable amounts of methane were formed in the water supplemented with DMSP while methane concentrations in the control bottles remained unchanged. DGGE- as well as FISH-analyses revealed a clear 


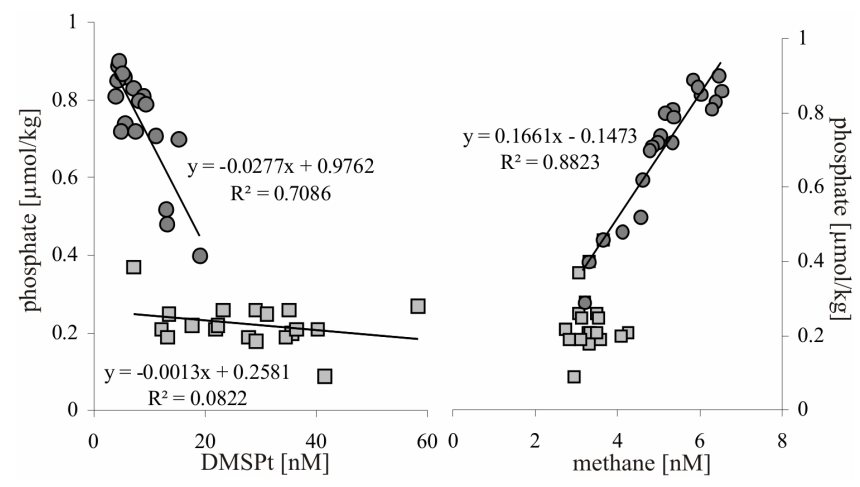

Fig. 3. Relationship between phosphate and DMSPt (left panel) and phosphate and methane (right panel) for water samples from the central Arctic Ocean. Circles and squares correspond to Pacific and Atlantic derived surface water $(<50 \mathrm{~m})$, respectively. In Pacific-derived water, phosphate is inversely correlated with DMSPt and correlates with methane, while in Atlantic-derived water, no correlations exist.

alteration of the bacterial communities in the DMSP-spiked bottles. After 8 days the originally diverse DGGE-pattern with several light bands, had reduced to 3 dominant strong bands resembling the sequences found in the Pdw and closely related to sequences of uncultered Rhodobacter, Sulfitobacter, and Mesorhizobium types. The CARD-FISH analysis (Fig. 4) complemented this result showing that Archaea remained negligible in the DMSP supplemented approaches while Bacteria (hybridizing with the general bacterial probe) became nearly $100 \%$ of the community. After 8 days, alphaand gamma-proteobacteria together accounted for more than $75 \%$ of the DAPI-stained cells with the yet unsolved puzzle that no dominant gamma-proteobacterium sequence could be isolated. As in the Pdw samples, the nifH gene could be amplified from all three DMSP supplemented samples showing a clear increase over the course of the experiment. This further corroborates a close link between nitrogen fixation, DMSP degradation, and methane production by Eubacteria.

It was shown experimentally, in a phosphate-free environment, that methylphosphonate (MPn) acts as a precursor for methane production (Karl et al., 2008). We postulate that degradation products of DMSP may serve as precursors of methane if phosphate is available for bacteria. Although in phosphate-replete and phosphate-free environments respectively, bacteria utilize different $P$ sources, methyl groups are a common feature of the molecule structure of MPn and DMSP degradation products. Thus, methane formation by both precursors is likely to occur in oligotrophic sea water with methylotrophic methanogenesis being the potential pathway. A potential degradation product of DMSP and a potential direct precursor for methane is methanthiol which is produced by the demethylation and cleavage pathway (Kiene et al., 2000).

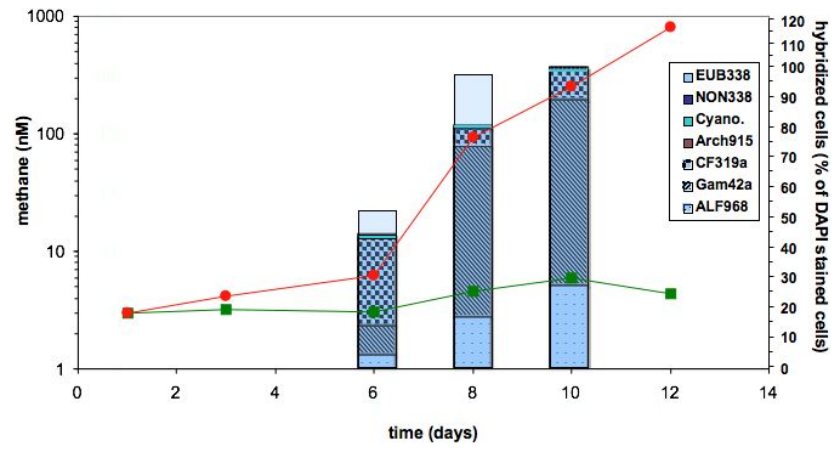

Fig. 4. Formation of methane during a microcosm experiment with Arctic surface water supplemented with DMSP (red line, closed circles) and without DMSP (green line, closed rectangles). A change in the bacterial community structure was followed up by CARDFISH using general probes to detect Bacteria, alpha- and gammaProteobacteria, Bacteroidetes. and Archaea, Cyanobacteria were determined by their morphology and yellow fluorescence at UVlight.

\subsubsection{Thermodynamic calculations}

Moran et al. (2008) proposed a new metabolic pathway for the anaerobic methane oxidation where methanethiol acts as an intermediate. The methanethiol is formed via two reactions, one dealing with oxidation of methane, the other, with reduction of $\mathrm{CO}_{2}$. These reactions are coupled in such a way that the reduction equivalents (like $\mathrm{H}_{2}$ ) released by methane oxidation are immediately used by $\mathrm{CO}_{2}$ reduction. Therefore, in the overall equation for methanethiol production, the contributions from the reduction equivalents cancel each other out. This tight coupling of the two half reactions minimizes the loss of reduction equivalents to competing oxidative reactions. The latter is an important issue, especially under aerobic environmental conditions. Here, we suggest that the pathway of methanethiol formation (Moran et al., 2008) operating in its reverse direction might also explain the production of methane. Hence, we propose the following methane formation reaction:

$\frac{4}{3} \mathrm{H}_{3} \mathrm{CSH}+\mathrm{H}_{2} \mathrm{O} \rightarrow \mathrm{CH}_{4}+\frac{1}{3} \mathrm{HCO}_{3}^{-}+\frac{5}{3} \mathrm{H}^{+}+\frac{4}{3} \mathrm{HS}^{-}$

The Gibbs free energy change $(\Delta G)$ for reaction (1) can be calculated using the following equation:

$$
\Delta G=\Delta G^{0^{\prime}}+R \cdot T \cdot \ln \frac{\left[\mathrm{CH}_{4}\right] \cdot\left[\mathrm{HCO}_{3}^{-}\right]^{1 / 3} \cdot\left[\mathrm{HS}^{-}\right]^{4 / 3}}{\left[\mathrm{H}_{3} \mathrm{CSH}\right]^{4 / 3}}
$$

( $T$ is the Temperature in Kelvin, $R$ is the universal gas constant, $\left[\mathrm{H}_{3} \mathrm{CSH}\right],\left[\mathrm{CH}_{4}\right],\left[\mathrm{HCO}_{3}^{-}\right]$and $\left[\mathrm{HS}^{-}\right]$designate concentrations in $\mathrm{mol} / \mathrm{L}$ ). For a reaction under physiological conditions it is more appropriate to define the reference $\left[\mathrm{H}^{+}\right]$ differently from the standard concentration of $1 \mathrm{M}(\mathrm{pH}=0)$. The Gibbs free energy change at the appropriate neutral $\mathrm{pH}$ 
and with all reaction partners, except protons, kept at standard concentrations is labeled $\Delta G^{0}$. It is calculated for reaction (1) from

$\Delta G^{0^{\prime}}=\Delta G_{(T)}^{0}-2.3026 \cdot R \cdot T \cdot\left(\frac{5}{3}\right) \cdot \mathrm{pH}$

where $\Delta G_{(T)}^{0}$ is the free energy change at standard concentrations of all reaction partners corrected for temperature. The $\Delta G_{(T)}^{0}$ at an actual temperature $(T)$ can be calculated from the free energy change at the standard reference temperature $\left(T_{\text {ref }}=298.15 \mathrm{~K}\right)$ by means of the van't Hoff equation (Atkins, 1990)

$\Delta G_{(T)}^{0}=\Delta G_{\left(T_{\text {ref }}\right)}^{0} \cdot \frac{T}{T_{\text {ref }}}+\Delta H_{\left(T_{\text {ref }}\right)}^{0} \cdot \frac{T_{\text {ref }}-T}{T_{\text {ref }}}$

with $\Delta H_{\left(T_{\text {ref }}\right)}^{0}$ being the standard free enthalpy change at temperature $T_{\text {ref. }}$. The derivation of Eq. (4) assumes that $\Delta H_{\left(T_{\text {ref }}\right)}^{0}$ is not greatly changed from $\Delta H_{(T)}^{0}$ within a (physiologically reasonable) temperature interval $T-298.15 \mathrm{~K}$. It is usually true that $\Delta H_{(T)}^{0}$ for reactions varies rather slowly with $\mathrm{T}$, provided no phase changes occur in the temperature interval. $\Delta G_{\left(T_{\text {ref }}\right)}^{0}$ and $\Delta H_{\left(T_{\text {ref }}\right)}^{0}$ and in turn $\Delta G_{(T)}^{0}$ can be calculated with the tabulated values of standard free energies and enthalpies of formation from the elements for $\mathrm{H}_{2} \mathrm{O}_{(l)}$, $\mathrm{H}_{3} \mathrm{CSH}_{(g)}, \mathrm{CH}_{4(g)}, \mathrm{HCO}_{3}^{-}$, and $\mathrm{HS}^{-}$(Lide, 1999). Since reaction (1) proceeds in the aqueous phase, the value of $\Delta G_{(T)}^{0}$ is corrected for the dissolution of $\mathrm{H}_{3} \mathrm{CSH}_{(g)}$ and $\mathrm{CH}_{4(g)}$ in water using the Henry's law constant $\left(k_{H}\right)$, which describes the equilibrium partitioning of $\mathrm{H}_{3} \mathrm{CSH}$ and $\mathrm{CH}_{4}$ between the gas and the aqueous phase: $\Delta_{\operatorname{soln}} G_{(T)}^{0}=-R \cdot T \ln k_{H}$. The temperature dependence of $\mathrm{k}_{H}$ is given by the equation:

$k_{H}=k_{H, T_{\text {ref }}} \cdot \exp \left[\frac{-\Delta_{\text {soln }} H}{R} \cdot\left(\frac{1}{T}-\frac{1}{T_{\text {ref }}}\right)\right]$

where $\Delta_{\text {soln }} H$ is the enthalpy of dissolution. The values of the Henry's law constants at standard conditions $\left(k_{H, T_{\text {ref }}}\right)$ and of $\Delta_{\text {soln }} H$ are available from Sander (1999) (methane: $k_{H, T_{\text {ref }}}=1.3 \times 10^{-3} \mathrm{M} / \mathrm{atm}$ and $-1 / R \times \Delta_{\text {soln }} H$ $=1800 \mathrm{~K}$; methanethiol: $k_{H, T_{\text {ref }}}=2.0 \times 10^{-1} \mathrm{M} / \mathrm{atm}$ and $\left.-1 / R \times \Delta_{\text {soln }} H=2800 \mathrm{~K}\right)$. At the environmental temperature of $2{ }^{\circ} \mathrm{C}$ it follows from Eqs. (3-5) that reaction (1) is exergonic under standard conditions at the intracellular $\mathrm{pH}$ of $7\left(\Delta G^{0^{\prime}}=-33 \mathrm{KJ} \mathrm{mol}^{-1}\right)$. Using our result for $\Delta G^{0^{\prime}}$, the Gibbs free energy change $(\Delta G)$ for the actual concentrations of the reaction partners can be calculated by means of Eq. (2). We simulate respiration within the cell by assuming $\left[\mathrm{HCO}_{3}^{-}\right]$ $=30 \mathrm{mM}$ and $\left[\mathrm{HS}^{-}\right]=1 \mathrm{mM}$. From the field data we estimate $\left[\mathrm{H}_{3} \mathrm{CSH}\right]=1 \mathrm{nM}$ and $\left[\mathrm{CH}_{4}\right]=10 \mathrm{nM}$. Then, the Gibbs free energy change that derives from Eq. (2) is given by $\Delta G=$ $-35.7 \mathrm{KJ} \mathrm{mol}^{-1}$. Thus, for the assumed concentrations of the reaction partners energy is released during methane formation. Since $\mathrm{N}_{2}$-fixation is a highly energy consuming process, methane production could contribute additional free energy for bacterial growth.
A bacterial cell needs a minimum of about $-20 \mathrm{KJ}$ per mol to exploit the $\Delta G$ in a metabolic reaction ("biological energy quantum", Schink, 1997). Hence, our result for $\Delta G$ of $-35.7 \mathrm{KJ} \mathrm{mol}^{-1}$ indicates that methane production via reaction (1) is consistent with the constraints of thermodynamics and the biological energy quantum. It should be noted here, that $\Delta G$ of reaction (1) calculated for the high intracellular $\left[\mathrm{HCO}_{3}^{-}\right]$and $\left[\mathrm{HS}^{-}\right]$represents a conservative estimate. The methane production via reaction (1) becomes more favorable for seawater concentrations at $\mathrm{pH}=8.2$ $\left(\Delta G<-35.7 \mathrm{KJ} \mathrm{mol}^{-1}\right)$.

The pathway for the reaction (1) suggested by Moran et al. (2008) involves CoM which is so far only found in anaerobic methanogenic Archeabacteria. There is no proof for its presence in aerobic seawater. However, there is a structural similarity between CoM and MPA (Mercaptopropionate), which is a further product of aerobic demethylation of DMSP. Hence, the MPA might substitute for CoM in the formation of methane.

\section{Conclusions}

In the central Arctic Ocean a shift from a phytoplankton bloom situation to oligotrophic conditions occurs during summer both in Atlantic and Pacific derived water where nitrate limits primary production. Nitrate depletion appears to be a primary requirement for methane production in aerobic surface water. A second pre-condition in the high latitudes is the phosphate excess, which may be utilized by bacteria as a $\mathrm{P}$ source. Where phosphate is available as a source of $\mathrm{P}$, methylated compounds like DMSP and its degradation products may serve as the bacterial $\mathrm{C}$ source. When a combination of these conditions exists, methane may be a metabolic by-product and its production could yield energy under aerobic conditions. However, to prove the proposed mechanism ongoing research is required.

Methane production may occur as a rapid response to environmental perturbations during the shift from a phytoplankton bloom to an oligotrophic system, induced by a switch in the utilization of phosphate and methylated compounds. Hence, methane production in aerobic surface water is directly linked to the $\mathrm{N}, \mathrm{P}$ and $\mathrm{C}$ cycles. Recent change in the Arctic has altered seasonal ice coverage and density stratification of surface water, which may have profound effects on these biogeochemical cycles. Thus, feedback effects on cycling pathways of the climatically relevant biogases methane and DMS are likely, with DMSP catabolism in high latitudes possible contributing to a warming effect on the earth's climate through production of the greenhouse gas, methane. 
Acknowledgements. We are grateful to Ingrid Stimac and Jutta Jürgens who participated in the work at sea and in the home lab. We thank the scientific party and crew of RV Polarstern for their support at sea. The participation of R. P. Kiene was supported by grants OPP-0230497 and OCE-0724017 from the US National Science Foundation.

Edited by: S. W. A. Naqvi

\section{References}

Atkins, P. W.: Physical Chemistry, 4. Edn., Oxford University Press, Oxford, 1990.

Boulygina, E. S., Kuznetsov, B. B., Marusina, A. I., Tourova, T. P., Kravchenko, I. K., Bykova, S. A., Kolganova, T. V. and Galchenko, V. F.: A study of nucleotide sequences of nifH genes of some methanotrophic bacteria. Microbiology (English translation of Mikrobiologiya) 71, 425-432, 2002.

Carmack, E. C., Aargard, K., Swift, J. H., McDonald, R. W., McLaughlin, F. A., Jones, P. E., Perkin, R. G., Smith, J. N., Ellis, K. M. and Killius, L. R.: Changes in temperature and tracer distributions within the Arctic Ocean: Results from the 1994 Arctic Ocean section, Deep-Sea Res Pt. II, 44(8), 1487-1502, doi:10.1016/S0967-0645(97)00056-8, 1997.

Charlson, R. J., Lovelock, J. E., Andreae, M. O. and Warren, S. G.: Oceanic phytoplankton, atmospheric sulphur, cloud albedo and climate, Nature, 326, 655-661, 1987.

Craig, H.: Isotopic standards for carbon and oxygen and correction factors for mass-spectrometric analysis of carbon dioxide, Geochim. Cosmochim. Ac., 12, 133-149, 1957.

Curran, M. A. J., Jones, G. B. and Burton, H.: Spatial distribution of dimethylsulfide and dimethylsulfoniopropionate in the Australian sector of the southern Ocean, J. Geophys. Res., 103, 16667-16689, 1998.

Damm, E., Mackensen, A., Budeus, G., Faber, E. and Hanfland, C.: Pathways of methane in seawater: Plume spreading in an Arctic shelf environment (SW-Spitsbergen), Cont. Shelf Res., 25, 1433-1452, 2005.

Damm, E., Schauer, U., Rudels, B., and Hass, C.: Excess of bottom-released methane in an Arctic shelf sea polynya in winter, Cont. Shelf Res., 27, 1692-1701, doi:10.1016/j.csr.2007.02.003, 2007.

Damm, E., Kiene, R.P., Schwarz, J. Falck, E. and Dieckmann, G.: Methane cycling in Arctic shelf water and its relationship with phytoplankton biomass and DMSP, Mar. Chem., 109, 45-59, 2008.

Dedysh, S. N., Ricke, P. and Liesack, W.: NifH ans NifD phylogenies: an evolutionary basis for understanding nitrogen fixation capabilities of methanotrophic bacteria, Microbiology, 150, 1301-1313, 2004.

Edler, L.: Recommendations on methods for marine biological studies in the Baltic Sea, Phytoplankton and chlorophyll, BMB Publ., 5, 1-38, 1979.

Evans, C. A. and O'Reily, J. E.: A handbook for the measurement of chlorophyll $a$ in netplankton and nanoplankton, BIOMASS Handbook, 9, 1-14, 1987.

Forster, G., Upstill-Godard, R. C., Gist, N., Robinson, C., Uher, G., and Woodward, E. M. S.: Nitrous oxide and methane in the Atlantic Ocean between $50^{\circ} \mathrm{N}$ and $52^{\circ} \mathrm{S}$ : Latitudinal distribution and sea-to-air flux, Deep-Sea. Res. Pt. II, 56, 964-976, doi:10.1016/jdsr2.2008.12.002, 2008.

Gallon, J. R.: Tansley Review No. 44, Reconciling the incompatible: $\mathrm{N}_{2}$ fixation and $\mathrm{O}_{2}$, New Phytol., 122, 571-609, 1992.

Gerdes, B., Brinkmeyer, R., Dieckmann, G., and Helmke, E.: Influence of crude oil on changes of bacterial communities in Arctic sea-ice, FEMS Microbiology Ecology, 53, 129-139, 2005.

Grasshoff, K., Ehrhardt, M., and Kremling, K.: Methods of seawater Analysis. Verlag Chemie, Weinheim, 419 pp, 1983.

Gruber, N. and Sarmiento, J. L.: Global patterns of nitrogen fixation and denitrification, Global Biogeochem. Cy., 11, 235-266, 1997.

Hobbie, J. E., Daley, R. J. and Jasper, S.: Use of Nuclepore filters for counting bacteria by fluorescence microscopy, Appl. Environ. Microbiol., 33, 1225-1228, 1977.

Jeong, K. S., Cho, J. H., Kim, S. R., Hyun, S., and Tsunogai, U.: Geophysical and geochemical observations on actively seeping hydrocarbon gases on the south-eastern Yellow Sea continental shelf, Geo-Mar. Lett., 24, 53-62, 2004.

Jones, P. E., Anderson, L. G. and Swift, J. H.: Distribution of Atlantic and Pacific waters in the upper Arctic Ocean: Implications for circulation; Geophys. Res. Lett., 25(6), 765-768, 1998.

Jones, P. E., Anderson, L. G., Jutterström, S., Mintrop, L., and Swift, J. H.: Pacific freshwater, river water and sea ice meltwater across Arctic Ocean basins: Results from the 2005 Beringia Expedition, J. Geophys. Res, 113, C08012, doi:10.1029/2007JC004124, 2008.

Karl, D. M., Beversdorf, L., Björkman, K., Church, M. J., Martinez, A., and DeLong, E. F.: Aerobic production of methane in the sea, Nat. Geosci., 1, 473-478, doi:10.1038/ngeo234, 2008.

Kiene, R. P.: Methane, Nitrogen Oxides and Halomethanes, in: Microbial Production and Consumption of Greenhouse Gases, edited by: Rogers, J. E. and Whitman, W. B., 111-146, ASM Washington DC, 1991.

Kiene, R. P., Linn, L. J and Bruton, J. A.: New and important roles for DMSP in marine microbial communities, J. Sea Res., 43, 209-224, 2000.

Kvenfolden, K., Lilley, M., Lorenson, T. D., Barnes, P. W. and McLaughlin, E.: The Beaufort Sea continental shelf as a seasonal source of atmospheric methane, Geophys. Res. Lett., 20, 2459-2462, 1993.

Lammers, S., Suess, E., and Hovland, M.: A large methane plume east of Bear Island (Barents Sea): implications for the marine methane cycle, Geol. Rundsch., 84, 59-66, 1994.

Lamontagne, R. A., Swinnerton, J. W., Linnebom, V. J. and Smith, W. D.: Methane concentrations in various marine environments, J. Geophys. Res., 78, 5317-5324, 1973.

Lide, D. R.: CRC Handbook of Chemistry and Physics, 80. Edn., CRC Press, Inc., Boca Raton, FL, 1999.

Moran, J. J., Beal, E. J., Vrentas, J. M., Orphan, V. J., Freeman, K. H., and House, C. H.: Methyl sulphides as intermediates in the anaerobic oxidation of methane, Environ. Microbiol., 10, 162173, 2008.

Moran, M. A., Gonzalez, J. M., and Kiene, R. P.: Linking a bacterial taxon to sulfur cycling in the sea: studies of the marine Roseobacter group, Geomicrobiol. J., 20, 375-388, 2003.

Moran, M. A., Belas, R., Schell, M. A., Gonzalez, J. M., Sun, F., Sun, S., Binder, B. J., Edmonds, B., Ye, J. W., Orcutt, B., Howard, E. C., Meile, C., Palefsky, W., Goesmann, A., Ren, Q., 
Paulsen, I., Ulrich, L. E., Thompson, L. S., Saunders, E. and Buchan, A.: Ecological genomics of marine Roseobacters, Appl. Environ. Microbiol., 73, 4559-4569, 2007.

Murphy, J. and Riley, J. P.: A modified single solution method for the determination of phosphate in natural waters, Anal. Chim. Acta, 27, 31-36, 1962.

Myzer, G., de Waal, E., and Uitterlinden, A.: Profiling of complex microbial populations by denaturing gradient gel electrophoresis analysis of polymerase chain reaction-amplified genes coding for 16S rRNA, Appl. Environ. Microbiol., 59, 695-700, 1993.

Pabi, S., v. Dijken, G. L., and Arrigo, K. R.: Primary production in the Arctic Ocean, 1998-2006, J. Geophys. Res., 113, CO8005, doi:10.1029/2007JC004578, 2008.

Pernthaler, A., Pernthaler, J., and Amann, R.: Fluorescence in situ hybridization and catalyzed reporter deposition for the identification of marine bacteria, Appl. Environ. Microbiol., 68, 30943101, 2002.

Pinhassi, J., Simo, R., Gonzalez, J. M., Vila, M., Alonso-Saez, L., Kiene, R. P., Moran, M. A., and Pedros-Alio, C.: Dimethylsulfoniopropionate turnover is linked to the composition and dynamics of the bacterioplankton assemblage during a microcosm phytoplankton bloom, Appl. Environ. Microbiol., 71, 7650-7660, 2005.

Rabe, B., Schauer, U., Mackensen, A., Karcher, M., Hansen, E., and Beszczynska-Möller, A.: Freshwater components and transports in the Fram Strait - recent observations and changes since the late 1990s, Ocean Sci., 5, 219-233, 2009, http://www.ocean-sci.net/5/219/2009/.

Sakshaug, E.: Primary and secondary production in the Arctic Seas, in The Organic Carbon Cycle in the Arctic Ocean, edited by: R. Stein and R.W. McDonald, 57-81, Springer, Berlin, 2003.

Sander, R.: Compilation of Henry's Law Constants for Inorganic and Organic Species of Potential Importance in Environmental Chemistry (Version 3), http://www.henrys-law.org, 1999.

Schauer, U.: The expedition ARKTIS-XXII/2 of the research vessel "Polarstern" in 2007. Reports on Polar and Marine Research, AWI, Bremerhaven, 579, 2008.

Schink, B.: Energetics of syntrophic cooperation in methanogenic degradation, Microbiol. Mol. Biol. Rev., 61, 262-280, 1997.
Scranton, M. I. and Brewer, P. G.: Occurrence of methane in the near surface waters of the western subtropical North-Atlantic, Deep-Sea Res., 24, 127-138, 1977.

Shakhova, N. and Semiletov, I.: Methane release and coastal environment in the East Siberian Arctic shelf, J. Marine Syst., 66, 227-243, 2007.

Simo, R., Archer, S. D., Pedros-Alio, C., Gilpin, L., and StelfoxWiddicombe, C. E.: Coupled dynamics of dimethylsulfoniopropionate and dimethylsulfide cycling and the microbial food web in surface waters of the North Atlantic, Limnol. Oceanogr., 47, 53-61, 2002.

Stefels, J.: Physiological aspects of the production and conversion of DMSP in marine algae and higher plants, J. Sea Res. 43, 183197, 2000.

Tallant, T. C. and Krycki, J. A.: Methylthiol: coenzyme M methyltransferase from methanosarcina barkeri, an enzyme of methangenesis from dimethylsulfide and methylmercatopropionate, J. Bacteriol., 179, 6902-6911, 1997.

Thingstad, T. F., Bellerby, R. G. J., Bratbak, G., Borsheim, K. Y., Egge, J. K., Heldal, M., Larsen, A., Neill, C., Nejstgaard, J., Norland, S., Sandaa, R. A., Skjoldal, E. F., Tanaka, T., Thyraug, R., and Töpper, B.: Counterintuitive carbon-to-nutrient coupling in an Arctic pelagic ecosystem, Nature, 455, 387-390, doi:10.1038/nature07235, 2008.

Wallner, G., Amann, R., and Beisker, W.: Optimizing fluorescence in situ hybridization with ribosomal-RNA-targeted oligonucleotide probes for flow cytometric identification of microorganisms, Cytometry, 14, 136-143, 1993.

Woodgate, R. A., Aagaard, K., and Weingartner T. J.: A year in the physical oceanography of the Chukchi Sea: Moored measurements from autumn 1990-1991, Deep-Sea Res. Pt. II, 52, 3116-3149, doi:10.1016/j.dsr2.2005.10.016, 2005.

Yamamoto-Kawai, M., Carmack, E. C., and McLaughlin, F. A.: Nitrogen balance and Arctic throughflow, Nature, 443, 43, 2006.

Zehr, J. P. and McReynolds, L. A.: Use of degenerate oligonucleotides for amplification of nifH gene from the marine cyanobacterium Trichodesmium thiebautii, Appl. Environ. Microbiol., 55, 2522-2526, 1989. 